For personal use only. Not to be reproduced without permission of the publisher (editorial@gabi-journal.net).

\section{Promoting a competitive generics market in the US}

As a result of recent price increases and shortages, the US generics market has come under increasing scrutiny [1]. In a recent report by Wiske et al., authors from Brown, Duke and Harvard Universities discussed ways to increase the competitiveness of the US generics market as a possible way to address these problems [2].

Generics price increases in the US were highlighted in August 2015 after Turing Pharmaceuticals increased the price of its newly acquired 62-year-old infectious disease drug Daraprim (pyrimethamine) from US $\$ 13.50$ a tablet to US\$750 - a 5,000\% price hike [3]. Then, fellow generics maker Valeant Pharmaceuticals, in a single day, raised the price of two generic drugs, Nitropress (nitroprusside) - a vasodilator used to reduce blood pressure, and Isuprel (isoprenaline) - used for the treatment of bradycardia (slow heart rate), by $212 \%$ and $525 \%$, respectively [4]. Despite action by the US Food and Drug Administration (FDA) to try and combat them, generic drug shortages, $73 \%$ of which involve injectable generics, remain a major problem in the US [5].

Wiske et al. highlighted two features of the US generics market that make it more prone than other markets to price swings and shortages:

1. Entry is restricted by financial barriers (costs of product formulation, quality assurance and bioequivalence testing) and time barriers (abbreviated clinical testing and the abbreviated new drug application review cycle).

2. Barriers exist to substitution of other products.

In 2014, generics accounted for $88 \%$ of prescriptions and $28 \%$ of pharmaceutical spending in the US. It is therefore important to provide a stable supply of affordable generics. This will in turn help eliminate price swings and shortages. In order to do this, Wiske et al. suggested three options to create a generics market that could make it more economically viable for several firms to supply each generic drug product on the market.

\section{Option 1: Restrict market entry}

Currently, there are no restrictions on the number of firms that can enter a given generics market. The authors suggest that FDA could instead offer a limited number of licenses to suppliers for each generic drug. This, they say, 'could bring greater transparency to the generics market, paradoxically attracting more manufacturers to remain as suppliers'.

Risks involved with this option include the fact that offering too few or too many licenses may return prices to monopolistic levels. In addition, some firms granted licenses may choose not to exercise the right to do so. To counteract this, the authors suggest that FDA could incorporate a claw-back provision into the license so that winning bidders that chose not to supply the product would lose their licenses to other bidders.

\section{Option 2: Encourage long-term contracts from wholesalers}

The supply chain for generics is complex and firms that are unable to secure a contract with large distributors are likely to exit the market. Therefore, if distributors established long-term contracts with generics makers the authors argue would ensure greater predictability in wholesale drug demand and supply and encourage more suppliers to remain in the market. The authors suggest that to encourage adoption of this model the government could provide tax incentives to distributors for the value of their inventories or for the contract value of future generics purchase commitments.

The risk with this option is that distributors would bear large financial risks if the standard of care changes rapidly, resulting in unused inventory that would effectively have no recovery value.

\section{Option 3: Create a futures market}

Trading generics on an open market, similar to a futures market, could work in a way similar to long-term contracts with distributors. Futures trading involves virtual markets in which interested parties can trade a contract for a fixed amount of a commodity to be delivered at a future time under various conditions. This could help generics makers predict demand for products, thus decreasing long-term financial volatility and creating greater transparency about drug prices.

The risk with this option is that speculation in the market could increase the volatility of option prices. The financial instruments in this market would also be complex, due to the wide variety of generic drug products. The authors suggest however that existing market regulators, such as the Commodity Futures Trading Commission, could help oversee the establishment and successful conduct of such a generics futures market.

The authors conclude that price increases and shortages are the result of the structure of the generics market in the US. They present three options designed to make excessive price increases and shortages less likely by addressing the problems associated with the current generics market economic model.

\section{Conflict of interest}

The authors of the research paper [2] declared that Dr Schulman has received honoraria and consulting fees from pharmaceutical companies. The other authors did not report any conflicts of interest. For full details of the authors' conflicts of interest, see the research paper [2].

\section{Competing interests: None.}

Provenance and peer review: Article abstracted based on published scientific or research papers recommended by members of the Editorial Board; internally peer reviewed.

Michelle Derbyshire, PhD, GaBI Online Editor

\section{References}

1. GaBI Online - Generics and Biosimilars Initiative. Soaring generics prices come under increased scrutiny [www.gabionline.net]. Mol, Belgium: Pro Pharma Communications International; [cited 2015 Dec 15]. Available from: www.gabionline. net/Generics/General/Soaring-generics-prices-come-under-increased-scrutiny

2. Wiske CP, Ogbechie OA, Schulman KA. Options to promote competitive generics markets in the United States. JAMA. 2015;314(20):2129-30.

3. GaBI Online - Generics and Biosimilars Initiative. Senator calls for FTC to investigate drugmakers for antitrust violations [www.gabionline.net]. Mol, Belgium: Pro Pharma Communications International; [cited 2015 Dec 15]. Available from: www.gabionline.net/Policies-Legislation/Senator-calls-for-FTCto-investigate-drugmakers-for-antitrust-violations

References 4 to 5 can be found on page 41 .

Submitted: 15 December 2015; Revised: 15 December 2015; Accepted: 15 December 2015; Published online first: 16 December 2015 
Promoting a competitive generics market in the US

References (please see the full manuscript on page 45)

4. GaBI Online - Generics and Biosimilars Initiative. US politicians form Affordable Drug Pricing Task Force [www.gabionline.net]. Mol, Belgium: Pro Pharma Communications International; [cited 2015 Dec 15]. Available from: www.gabionline.
net/Generics/General/US-politicians-formAffordable-Drug-Pricing-Task-Force

5. GaBI Online - Generics and Biosimilars Initiative. FDA announces two actions to combat drug shortages [www.gabionline.net]. Mol, Belgium: Pro Pharma
Communications International; [cited 2015 Dec 15]. Available from: www.gabionline.net/Pharma-News/

FDA-announces-two-actions-to-combat-drug-shortages DOI: 10.5639/gabij.2016.0501.011

Copyright $\odot 2016$ Pro Pharma Communications International 